\title{
The Development of Productivity Practical Management Model at Automotive Mechanical Technology Skill Program in Semarang Vocational Schools, Indonesia
}

\author{
Hadromi $^{1}$, Maman Rachman ${ }^{2}$, Soesanto $^{3} \&$ Tri Jaka Kartana ${ }^{4}$ \\ ${ }^{1}$ Technical Faculty Unnes, Semarang, Indonesia \\ ${ }^{2}$ Educational Faculty Unnes, Semarang, Indonesia \\ ${ }^{3}$ Graduate School Unnes, Semarang, Indonesia \\ ${ }^{4}$ Pancasakti University Tegal, Tegal, Indonesia \\ Correspondence: Hadromi, Gedung E1, Fakultas Teknik, Universitas Negeri Semarang, Gunungpati, Kota \\ Semarang, Jawa Tengah, Indonesia. E-mail: omi_unnes@yahoo.com
}

\author{
Received: November 28, 2014 Accepted: January 6, 2015 Online Published: April 28, 2015 \\ doi:10.5539/ies.v8n5p101 \\ URL: http://dx.doi.org/10.5539/ies.v8n5p101
}

\begin{abstract}
The purpose of this research is to develop automotive Mechanical Technology Skill Program (TMO) in Vocational School. The Research and Development (R\&D) object was done in SMK 1, 4 and 7 Semarang, Indonesia. The result was achieved productivity Practical Management Final Model at TMO skill Program in Vocational school named momanticproter. Momanticproter is an advanced study of functional planning management, action, and evaluation in man, money, method, material and minute aspects to productivity practical component including: practical document, material management, practical action, application method, media utilization, teacher competence and qualification management, job description management for teacher, ingredients and tools maintenance management, type management, ratio, and standard description of productivity practical means and infrastructure, and occupational health and safety system. The trial result limited by momanticproter having score result 3,69, and scope result having average score 3,49, so that productivity practical management model has a good category, and can be applied in SMK TMO skill program. Then momanticproter visibility study having average score 3,7 with very suit category. The momanticproter apply implication generally gives a chance to teachers, students to have integral understanding in practical material, and integrated productivity practical management. Especially for school administrator having implication to increase management ability both skill and managerial, for students having implication in motivation to optimize their potential because the practical evaluation does not only rest on an output but also influenced by process so that supporting the regularity of practical action and can encourage honesty, responsibility, working hard, and respecting others. The suggestion for school administrator is in order to: (a) getting stakeholder support, (b) increase teacher resource trough workshop and comparative study.
\end{abstract}

Keywords: model, management, practical, productivity, vocational school

\section{Introduction}

Vocational School (SMK) is a vocation high school (UU No. 20/2003). The function of vocational school has a strategic role in creating matters pertaining to manpower. The strategic position seems in many aspects (1) Vocational School is an integral part from a nation economy aspect (2) The vocational school quality reflects Indonesia main power quality those need to be developed to increase the competitive ability of Indonesia human resources and (3) Vocational school has a role to decrease the unemployed index both local and national scope.

Constitutionally many efforts have been done by government to increase the practical and in theory learning process in vocational school and the graduate quality by stating many policies in vocation field. The policies face to improvement process that orientates to graduate competence standard in every grade of the school. In a sequence of government constitutional policy to vocational high school in fact has not answered yet to increase graduate quality suitable in work and industry scope need (DUDI). This condition can be seen from the many of educated unemployed in Indonesia (Formal news of central java BPS No. 28/05/33/year.VI, May $7^{\text {th }}$ 2012). Seen 
by percentage of school accreditation, so the vocational school accreditation result only having 41 percent accredited A, 43 percent accredited B and 12.9 accredited C (Maulana, 2012).

This condition is related to vocational school human resource (VSHR). The result of the survey in SMK N 1,4 and 7 in 2013,shows that the teacher motivation to increase the quality was low. The post graduate teacher qualification orderliness SMK N 1: $14.29 \%$, SMK N 4: 16\%, and SMK $720 \%$ and the remain for graduate qualification, if it is seen from the practical facility shows that each machine types/tools/ limited ingredients quantity, so that the productivity practical happened in big group around $08-10$ students per practical group. This condition as an effect from the weakness of productivity practical action management in that vocational school. For building this capacity is needed vocation education management function application. Gullick and Urwich (1937), state the management function consists of planning, organizing, staffing, directing, coordinating, reporting, and budgeting with its acronym POSDCoRB.

The activity of productivity practical management started from needing analyzing, planning, organizing, supervising, and evaluating. The learning atmosphere can create harmonious and productive academic surroundings if the functions supported by the competence human resource suitable with its field. The suitable between the implementation of practical and in theory learning management functions with the duties of teacher resource are very important for developing the academic surroundings in the school. As the productivity practical management that was done in vocational school, the implementation of each learning management function professionally can produce the achievement of practical action purpose.

The general purpose of this research to develop the productivity practical model of the automotive mechanical skill program (TMO) in State Vocational School in Semarang, Indonesia. The result of this research hopefully can be useful for the developing of skill program of productivity practical management model TMO in State Vocation School in Semarang, Indonesia and finally can give regularity in productivity practical process and fulfill the student graduate competence standard.

\section{Review of Related Literature}

The relevant research was done by some experts, specifically there was no discussion about productivity practical management in vocational school. From the past result that related by management developing in vocational school as done by Lynch (2000), researched about reformation aim high school career and technical education reform in first decade 21 century. Based on the review result and creative and contemporary thought, opinion, and policy documents that influences from some vocational school stakeholders. Then, Adiviso (1999) researched about technical and vocational education (TVE) system to increase the school service quality that the equality arises as TVE management demand. The equality increasing will have relation with the industry effort level that needs main power from vocational school. This condition is suitable with the Lewis research (2002), states that the effect of technology change in industry to the work that related by the workshop and education curriculum. Then Bailey and Robson (2002), state that the change of policy in England significantly in teacher workshop and development, and gives an effect in introducing of teacher professionalism standard at school, academy, and university. And the Kumar (2011) in his research states that to develop teacher achievement in learning process by developing the students' contribution in vocational school. The study talked about the primacy of the role of government policy, changes in technology and student involvement to enhance the role of vocational schools, and has not discussed the management functions of planning, implementation, and evaluation as an effort to improve the quality of vocational school.

Relating with the Wongkar (1990) management application stated in his research, that the education planning has not applied yet in schools according to the principles of education planning methodology, proved by the phenomena of procedural aspect development, substantive, integrated in education planning. Then Bakar Mohamed, and Hamzah (2013) did the research to identify the technical students skill from Industrial Training Institutes (ITI) and Indigenous People's Trust Council (MARA) Skills Training Institutes (IKM) in Malaysia. The result of this research shows that there is no significant change in work skill between the participants from IKM and ITI in gender matter, work experience and courses. This study reveals the primacy of vocational education management, but has not specifically discuss the components of productive practices such as practical document, material management, practical action, application method, media utilization, teacher competence and qualification management, job description management for teacher, ingredients and tools maintenance management, type management, ratio, and standard description of productivity practical means and infrastructure, and occupational health and safety system.

Next, relating by productivity practical tool, Dewhurst (1994), concludes that software using helps the laboratory work learning process. This condition cleared by Mohlelr (2007), states that spatial ability learning in student is 
impossible to be said verbally. The right teaching method taught by steps, pictorial drawing process. Then, Berner (2009) in his research about the new technology workshop for vocational students, need to notify: (1) self focus about how a new learner learned and understand the new difficult tasks. (2) Suitable with daily works (3) the technical detail of the task must be noticed briefly. Then J. H. Boyet and J. T. Boyet (2001) conclude in their writing that the knowledge of work principle relates with what, why and how doing something and must be supported by procedural knowledge. From the past researcher, there was no specifically discussion about productivity practical management model in vocational school. Then Hadromi (2014) in his research concludes that model internships work based learning is a model of learning that could give of job experience or verb in the guidance of when practices, next it is said that learning is happening as a result of the activity at work also resulted in peeningkatkan life skill and soul entrepreneur a student. The discussion conducted on the role of information technology to enhance the learning process vocational school.

\section{Method}

This work is a research and development $(R \& D)$. $R \& D$ was carried out to research and develop the productivity practical management model of TMO skill program in SMK 1, 4, and 7 in Semarang, Indonesia. because at the vocational school accredited, ISO standards, and have good cooperation with the automotive industry. In this research, R\&D follows development steps of productivity that formulated by Borg and Gall (1989). The steps of the research as Figure 1

\subsection{Research}

The research was carried out trough literary and field study that was achieved from questionnaire result, observation, and interview so that can get the target profile, the profit and the weakness about productivity practical management model of TMO skill program in state vocational school in Semarang Indonesia. The result of this research creates productivity practical management factual model.

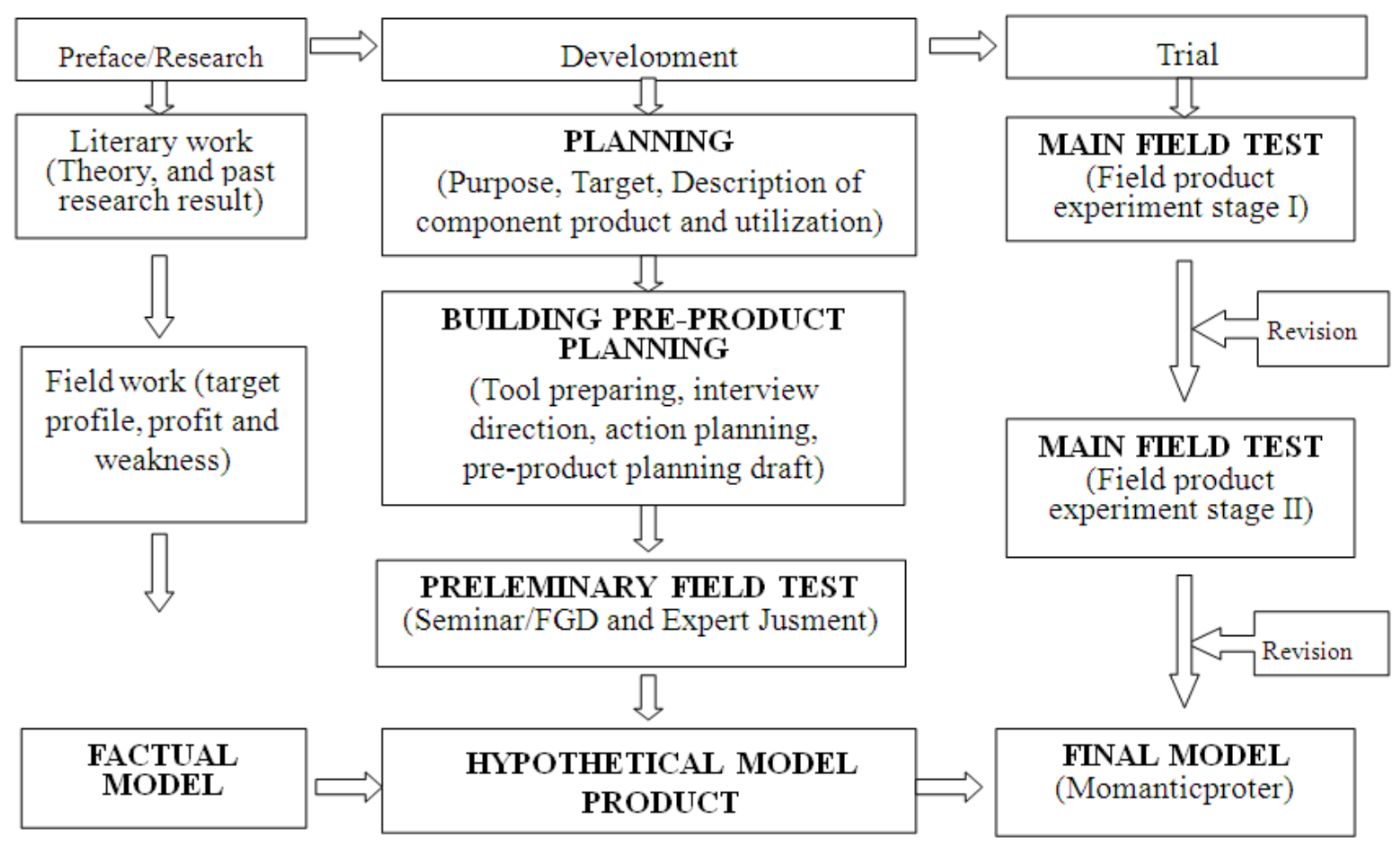

Figire 1. The stage of R\&D productivity practical management model in State Vocational School in Semarang Indonesia

The technical data analysis using quantitative and qualitative mix. The quantitative analysis was carried out trough data organizing that categorized based on four scale conversion. The qualitative data of productivity practical management was analyzed by using approach that was developed by Taylor and Powell (2003, pp. 2-6) with the stages (1) understanding the data, (2) focus the analysis, (3) categorizing information as cording the 
data or indexing the data, (4) identify patters and collection within and between categories, (5) interpretation-bringing it all together.

\subsection{Development}

The research results achieved factual model, the profit and the weakness, then develop model design (conceptual design) and carried out Preleminary Field Test through seminar/FGD and Expert Jusment. The stage result will achieve mortgage model. Then the mortgage model was tested limited and widely. The limited trial was carried out to principal, the head and teachers of TMO skill program in SMK N 1 Semarang, Indonesia number in six persons. The limited trial result was examined and then tested the wide trial. The wide trial action was carried out to principal, the head and teachers of TMO skill program in SMK N 4 and 7 Semarang, Indonesia, six persons for each school. The subject details of wide and limited product trial at table 1 . The result of wide trial creates final model of productivity practical management at TMO skill program in State vocational school in Semarang Indonesia.

Table 1. Research and development (R\&D) subject trial

\begin{tabular}{ccccc}
\hline NO & SMK & $\begin{array}{c}\text { Kriteria } \\
\text { Sekolah }\end{array}$ & Subyek Penelitian & $\begin{array}{c}\text { Trial } \\
\text { Types }\end{array}$ \\
\hline \multirow{2}{*}{1} & SMK N 1 & Accreditation & Principal, The Head of Skill Program, Productive & Limited \\
trial \\
\end{tabular}

\section{Result and Discussion}

\subsection{The Research Result}

The research result consists of (1) quantitative data about planning, action and productivity practical evaluation of TMO skill program in state vocational school in Semarang Indonesia that shown in Table 1, (2) qualitative data of observation and interview that analyzed using methods developed by Taylor and Powell (2003. pp. 2-6). From both of the data obtain factual model. The factual model has some weakness such as (1) the planning has not achieved yet the management principle, (2) then was carried out the factual model development.

Table 2. The data of productivity practical management factual model in TMO SMK skill program

\begin{tabular}{|c|c|c|c|c|c|}
\hline No & Planning Component & $\begin{array}{l}\text { Very Good } \\
(\%)\end{array}$ & $\begin{array}{l}\text { Good } \\
(\%)\end{array}$ & $\begin{array}{l}\mathrm{Bad} \\
(\%)\end{array}$ & $\begin{array}{l}\text { Very Bad } \\
(\%)\end{array}$ \\
\hline \multicolumn{6}{|c|}{ Productivity Practical Planning } \\
\hline 1 & $\begin{array}{l}\text { The teacher understanding of SAP, Syllabus and } \\
\text { Teaching Planning (RPP) }\end{array}$ & 44.44 & 55.56 & 0 & 0 \\
\hline 2 & $\begin{array}{l}\text { Productivity practical teacher making RPP appropriate } \\
\text { with the standard }\end{array}$ & 33.33 & 33.33 & 22.22 & 11.11 \\
\hline 3 & The productivity action appropriate with RPP & 33.33 & 44.44 & 22.22 & 0 \\
\hline \multirow[t]{2}{*}{4} & $\begin{array}{l}\text { The completeness and suitable module with the } \\
\text { productivity practical competence }\end{array}$ & 33.33 & 55.56 & 11.11 & 0 \\
\hline & Average & 36.1075 & 47.2225 & 13.8875 & 2.7775 \\
\hline \multicolumn{6}{|c|}{ Productivity practical action } \\
\hline 1. & $\begin{array}{l}\text { Suitability between productivity practical teacher } \\
\text { teaching duty and the competence }\end{array}$ & 88.89 & 11.11 & 0 & 0 \\
\hline
\end{tabular}


2. Suitability between productivity practical material and DUDI needs
11.11
66.66
11.11
11.11

3. Rotation and block model is a productivity practical model exactly applied in MTO Vocational School

$\begin{array}{llll}66.66 & 33.33 & 0 & 0\end{array}$

4. Suitability media used in productivity practise

$33.33 \quad 44.44$

11.11

Average

44.4425

36.1075

13.8875

5.555

\begin{tabular}{llllll}
\hline Productivity Practical Evaluation & & & & \\
\hline 1. & $\begin{array}{l}\text { Occur discussion between productive teachers in } \\
\text { evaluating productivity practical management }\end{array}$ & 44.44 & 44.44 & 11.11 \\
2. $\quad \begin{array}{l}\text { Good documentation result of productivity practical } \\
\text { management evaluation }\end{array}$ & 11.11 & 11.11 & 0 & 77.78 \\
3. $\quad \begin{array}{l}\text { The next evaluation result of productivity practical } \\
\text { management as a better steps } \\
\text { Average }\end{array}$ & 22.56 & 44.4 & 0 & 0 \\
\hline
\end{tabular}

The development stage carried out to reduce and to make disappear the weakness of the factual model. The development model was carried out by using conceptual model. Then the conceptual model validated using FGD and expert judgment so that achieved mortgage model. Then the mortgage model was tested using limited and wide trial and achieved final model named "Momanticproter" (Figure 1).

\subsection{Development Result}

The development result product is an integrated productivity practical management model named momanticproter (Figure 2). Momanticproter was developed as a planning management function, action, evaluation, and integrated designed in components man, money, method, material, and minute from 10 productivity practical components. The result of momanticproter proper trial is displayed as Table 3 . The achievement data having average score 3,7 with very proper category. So momanticproter is very proper to be applied in automotive mechanical skill program in vocational school in Semarang Indonesia as a productive practical learning model.

Tabel 3. The data of momanticproter proper trial

\begin{tabular}{lcc}
\hline Productive Practical Component & Average & Note \\
\hline Productive Practical Management Equipment & 3.7 & Very proper \\
Practical Management & 3.6 & Very proper \\
Practical Management & 3.7 & Very proper \\
Practical Media Management & 3.8 & Very proper \\
Practical Media Management & 3.7 & Very proper \\
The Development of Teacher Main Power Management & 3.6 & Very proper \\
The description of Teacher Duty Management & 3.7 & Very proper \\
Student Management & 3.6 & Very proper \\
Productive Practical tool/ingredients maintenance Management & 3.6 & Very proper \\
Ratio & 3.9 & Very proper \\
K3 System Management & 3.6 & Very proper \\
Final Score of Momanticproter Proper Trial & 3.7 & Very proper \\
\hline
\end{tabular}

The profit of momanticproter (1) practical action point: (a) productive practical direction and practical evaluation direction (b) point to the mastery learning (c) assistance and supervision attach, (d) There is an evaluation to the 
student progress process, (2) productive practical with a block model and integrated with rotation system, (3) Repairing and maintenance system (maintenance) (a) using maintenance principle based on the students, means routine maintenance that programmed when the students will and have carried out the practice. (b) there is a preventive maintenance, (c) maintenance guide, (4) type, ratio and practice room infrastructure standard oriented to the rule permen Diknas No. 40 year 2008. These profits are a new integrated productivity practical management' model.

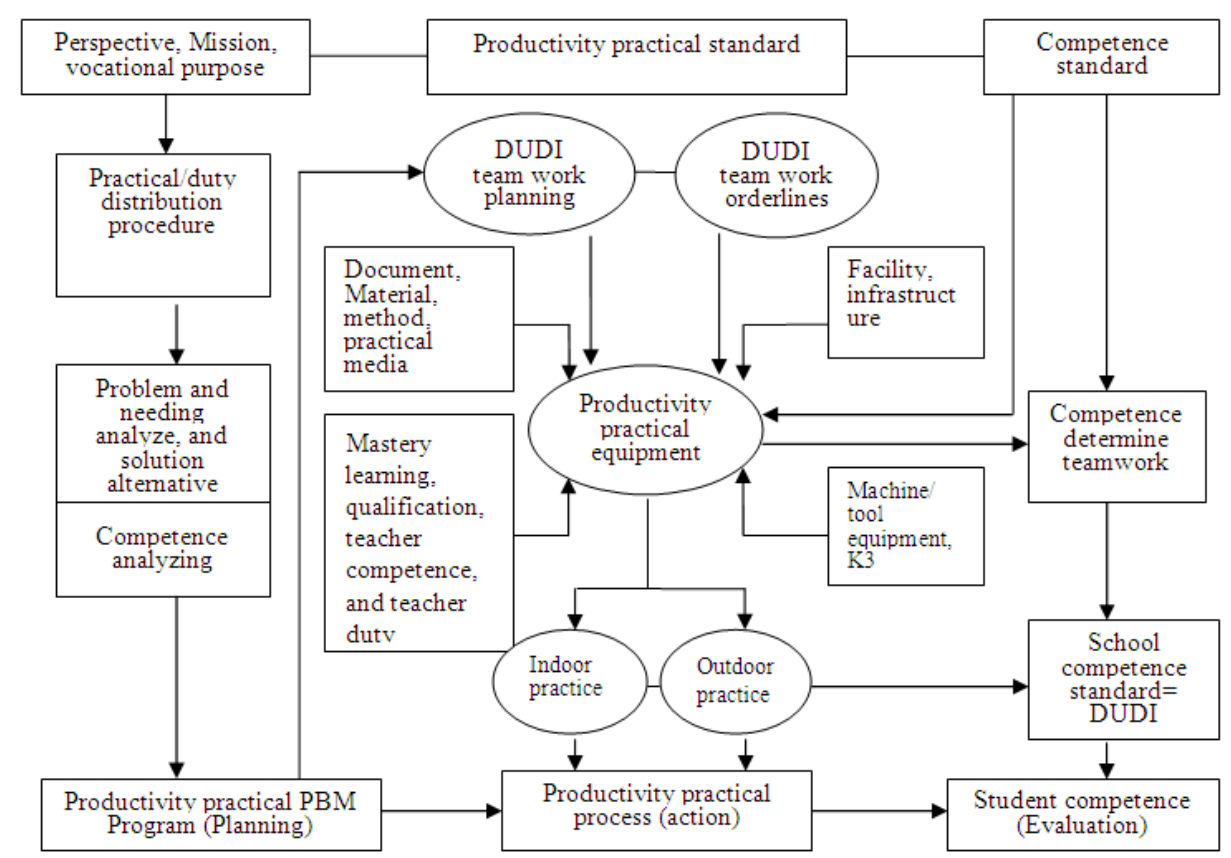

Figure 2. Final model: Momantikproter

\subsection{Discussion}

\subsubsection{Practical Management Planning of Productivity Program}

Education planning is an effort to face the future in determining priority policy, and education fee that considers the fact and activity in economic, social, and politic fields to develop the national education system potential fulfill nation and student needing that served by the system. Then Guruge (1972) said, education planning is a process to prepare the future activity in education developing. Education planning is an education investment that can be carried out by another developing activities based on economic considering, fee and social profit. Education planning is an rational application analyzed education developing process systematically head for making the education more effective and efficient and deals with the student and society purpose (Coombs, 1982).

In practical management of productivity program, the planning aspect includes all of the activities to carry out practical activity of productivity program, so it can be more comprehensive considering the economic, social, culture and environment aspects to reach out the practical purpose of the productivity program. So the planning in practical management of productivity program suitable with applying synoptic planning theory or system planning, system rational approach, comprehensive rational approach.

The application of synopsis planning theory was applied in planning the practical management of productivity program includes the planning such as: (1) practical equipment document management of productivity program inside (2) practical material organizing, (3) practical action of productivity program (4) application and choosing process in practical method of productivity program, (5) choosing and using the media in productivity program practical, (6) teacher competence and qualified developing management in automotive mechanic skill program, (7) teacher duty description management, (8) machine/tool maintenance management and practical ingredients of productivity program, (9) type, ratio, and practical room infrastructure standard description, (10) health and safety work aspect management. The Element including in this approach, generally describes into: (1) purpose 
determining (2) policy alternative identification, (3) the result average evaluation and (4) policy implementation, then formulated into planning stages includes: (a) problem knowing, (b), problem scope estimation (c) solving possibility classification, (d) problem investigation, (e) alternative prediction, (f) the aim evaluation in specific solving.

The base of the practical planning of productivity program necessary are (1) practical quality fixing of productivity program, (2) productivity program practice designed by approach system, (3) productivity program practical design point to the way learning, (4) productivity program practical design for per student, (5) productivity program practical design must be pointed to the aim, (6) productivity program practical design points to an easier learning, (7) productivity program practical design involves the practical variable, (8) productivity program practical design determines the aim achievement method.

\subsubsection{Productivity Program Practical Management Action}

The action of productivity program practical equipments involves (a) curriculum, (b) syllabus, (c) RPP, (d) teaching materials, (e) program practical schedule. The survey result in automotive mechanic skill program in state vocational school Semarang certifies that there are curriculum documentation, syllabus, RPP, and productivity program practical schedule. Not all of the schools have practical guiding, job sheet and operational sheet. This condition contains a consequence that the action to make perfect and repairing in vocational high schools to anticipate the need and future challenge must be carried out continuously, adapted by the developing of industrial scope, workplace developing, and knowledge, technology, art and business.

The processing of the productivity practical material needs to consider the curriculum, syllabus, RPP, tool and ingredients provided. The source of the practical PBM material taken from (a) new step book I, PT. Toyota Astra Motor, (b) step 2 engine book, PT. Toyota Astra Motor, (c) STM otomotif PT Toyota Astra Motor practical book and (d) Internet. The sources do not tie depend on the need in practical. The productivity program practical action in automotive mechanical skill program in state vocational school Semarang in good category. The student as a practical worker has an insurance. PBM practical order has been provided and documented in workplace. But the SOP PBM practical has not been provided in observation result.

The action of method choosing was carried out by teacher depend on the practical material, time, tools, ingredients and student ability. Block system is a practical model that proper applied in productivity program practical activity. Block system practical that the learning schedule distribution process based on accumulation hours amount that has determined in syllabus (curriculum) with the amount of accumulation learning hours assumption not less than the amount of accumulation hours learning determined in syllabus(curriculum).

The equipment of productivity program practical media consists of material, equipment, hardware, and software (Hadromi, 2011, p. 7). The material term has a correlation with the equipment term and the term of hardware has a correlation with software term. Material (media ingredients) is a tool that can be used to keep message turned to audiences using certain equipment or the thing, such as transpiration for overhead equipment, film, film script and slide film, picture, graph, and printed ingredient. While the equipment is a tool that used to move or deliver something kept by the material to the audience, examples car, engine, stand, slide film projector, video tape recorder, board, flannel board etc (Santyasa, 2007, p. 9).

The qualification of vocational high school teachers at least have Diploma 4 academic qualification or graduate (S1) suitable majoring with the subject learning and accredited. The condition of automotive mechanical skill program teachers in state vocational school Semarang are $82.93 \% \mathrm{~S} 1$ qualified teachers, and the others $17.07 \% \mathrm{~S} 2$ qualified teachers. The weakness of teacher interest to develop their qualifications because there is no promotion for their grade to S2 or S3, the contribution for their advanced education from the school only a stimulant with the limited tuition fee. According to Gilley and Eggland, 1989 in Ali (2002, p. 7), that HR development has three mission, they are individual development, career development, and organization development. The HR development is carried out through any activities that the focus point on the human competence development including in an organization or a foundation. The most conspicuous in HR development is carried out through education and workshop. The workshop continuously needs to be given to the educated HR. the continuously workshop needs to be given to the educated HR in their duty (On the job training). If we plan a professional human resource development, we need to review such as: policy, rules, and agreement and analyze the need. As told by Cho (2009, p. 1): "When planning your professional development, it is recommended that you review policies, regulations, and agreements and analyze needs."

Tool maintenance system, machine, and ingredients will minimize the damage in long period, but still have detriment such as product detriment as long as the machine stopping the operation (downtime) because of the maintenance (Jones, Guttenberger, \& Brenneke, 1991). To detect the damage, checking the machine and 
supervise in routinely. The interval supervising can be determined by using simple statistic method, commonly using price or MTBF value (mean time between failure) or average time between the damage from the machine history data (Levitt \& Joel, 2003). Meanwhile the machine condition can be examined by some technical ways, such as visual supervising, alert, and machine achievement (Mobley, 1990; Nakajima, 1989; Schlesinger, 1979).

Approach system in K3 management started by considering the occupational health and safety purpose, technical and equipments used, product process and workplace planning (Mangkunegara, 2001). K3 management system is a part from the whole management system consist of organization structure, planning action, responsibility, action, procedure, process and human resource needed for the development, evaluation and occupational health and safety maintenance to control the risk related to work activity to achieve safety workplace, efficient and productive (Santoso, 2004).

\subsubsection{Productive Program Practical Management Evaluation}

Productive program practical management evaluation is carried out by the Principal and the vice principal, the head of skill program, the productive program teachers and also the students evaluate the practical activity and determine if the organization function and the leader have carried it well to get the aim. Johnson (1978) stated based on Fayol's (1949) opinion, Mokler (1970), and Wiener (1950), that clarify the base of the control theory firstly of knowledge concept above the complex system control, information and communication, then clarified by Kemp (1993, p. 157) stated that there is no fixing in learning process without evaluated it well firstly to the learning process. Reigeluth (1993, p. 9) stated that teaching evaluation is related to understanding, increasing and doing the method as an evaluation to effective and efficiency for all the actions. Hamalik (1990, p. 259) says that evaluation is a process continuously about collecting and information explanation to assess the decisions to plan a teaching system.

The productivity practical management model evaluation of automotive mechanical skill program in state vocational school Semarang consist of: (1) productivity practical document management (2) practical material management, (3) productivity practical action (4) choosing process and method apply in productivity practical (5) choosing and using of the media in productivity practical 6) teacher competence and qualifying developing management in automotive mechanical skill program (7) the description of teacher duty management (8) productivity practical ingredients, equipment/tool maintenance management (9) type, ratio, and the description of practical room infrastructure standard (10) the occupational health and safety system, and (11) considering the support and hamper factors of productivity practical management in SMK Teknologi dan Rekaya Semarang.

The steps in doing first evaluation started by (1) collecting the determine data to get the real picture from the action of maintenance program applied. (2) determine or decide the expected condition from the maintenance program applied. (3) design the specification or standard of the maintenance/checking the machine condition. This card consists of machine identity, the part and work instruction, condition standard, equipment using and column to take a resume from the evaluation result (4) doing a trial and analyze or evaluation to the machine condition standard action.

\section{Conclusions}

The factual productivity practical management model of TMO skill program in state vocational school in Semarang has been developed becomes a mortgage so can get a momanticpoter. Momanticpoter based on the planning management function, action and integrated evaluation is designed to man, money, method, material components, and time. The momanticpoter limited trial result was has an average score 3,69, beside the average score in wide trial is 3,49 , with the model reserved level 3,7 in scale 4 . These limited and wide trial show that momanticpower is good and can be applied to TMO skill program in state vocational school. The profit of momanticpoter are (1) practical action points: (a) productivity practical guide, and there is a practical evaluation, (b) mastery learning applied (c) the assistance and pointed supervising (d) there is an evaluation to the student work progress (2) productivity program practice with the block model and integrated by rotation system (3) fixing and maintenance system: (a) using maintenance principle student based, (b) there is a preventive maintenance), (c) maintenance guide, (4) type, ratio and practical room infrastructure standard based on The Rule of permen Diknas No. 40 tahun 2008.

\subsection{Research Result Implication}

The momanticproter condition will give a chance to teacher, student to have integral understanding that is practical material understanding, the integrated productivity program practical management. The momanticproter applied implication give chances to teachers, students to have an integral understanding about practical material, integrated productivity program practical management, for the school organizer has an implication to develop the 
management ability, in material and in their skill, for student implicates in developing their motivation to optimize themselves potential because the practical evaluation is not only point to the output but also influenced by the process so that support the practical action activity and creates honest, responsibility, hard working, and appreciating each others.

\subsection{Suggestion}

The suggestion points to (1) school caretaker, expected: (a) getting support more intensively from the stakeholder, both government and DUDI, (b) developing the teacher competence more intensively through workshop and comparative study to the same type succeed school. (2) the suggestion for the researcher of education management for getting an advanced research especially to report or describe (a) the ideal student developing activity management model, (b) practical management model development in another skill programs, (3) the suggestion for Education Department, the Education Department applies momanticproter with sequences: (a) increase the subsidy especially for updating the machine/equipment/ingredients suit the industry needs (b) develop the teacher qualify and competence regularly and periodically suit the industry and school need.

\section{References}

Adiviso, B. F. (1999). Total quality management (TQM): Managing technical and vocational education through change. Journal of vocational and technical education, 16(1). Retrieved from http://scholar.lib.vt.edu/ejournals/JVTE/v16n1

Bailey, B., \& Robson, J. (2002). Changing teachers: A critical review of recent policies affecting the professional training and qualifications of teachers in schools, colleges and universities in England. Journal of Vocational Education and Training, 54(3), 325-342. http://dx.doi.org/10.1080/13636820200200203

Bakar, A. R., Mohamed, S., \& Hamzah, R. (2013). An Assessment of Workplace Skills Acquired by Students of Vocational and Technical Education Institutions. International Education Studies, 6(11).

Barnett, M. (2006). Using a web-based professional development system to support pre-service teachers in examining authentic classroom practice. Journal of Technology and Teacher Education, 14(4), 701-729. Retrieved from http://infotrac.galegroup.com/web

Bennie, K., \& Newstead, K. (1999). Obstacles to implementing a new curriculum.

Berner. (2009). The worker's dream of becoming an engineer. History and Technology: International Journal Vocations and Learning, 2(3), 177-194.

Borg, W. R., \& Gall, M. D. (1983). Educational research: An introduction to theory and methods. Boston: Allyn and Bacon. Inc.

Boyett, J. H., \& Boyett, J. T. (2001). The guru guide to the knowledge economy. Canada: John Wiley \& Sons.

Dewhurst, S. A., \& Conway, M. A. (1994). Pictures, images, and recollective experience. Journal of Experimental Psychology: Learning, memory, and Cognition, 20, 1088-1098.

Gullick, L., \& Urwicl, L. (1937). Papers on the Science of Administration. New York: Ohio, Columbia University Press.

Hadromi. (2011). Penerapan Model Pembelajaran Learning Cycle Berbasis Panel Peraga Sebagai Upaya Meningkatkan Kompetensi Mahasiswa Pada Materi Sistem Pengisian. Unnes. Laporan Penelitian LP2M Unnes.

Hadromi. (2014). Penerapan Model Internships Work Based Learning Pada Pembelajaran Praktik Untuk Meningkatkan Life Skill Dan Jiwa Entrepreneur Mahasiswa Pendidikan Vokasi. Jurnal Pendidikan Teknik Mesin, 14(1).

Jones, Guttenberger, \& Brenneke. (1991). Condition Monitoring '91. Proceeding of an International Conference on Condition Monitoring held at the Stadhalle. Erding, Germany, May 14-16th 1991, Peineridge Press, Swansea U.K.

Kumar, A. (2011). Student Evaluation of Teaching: An Instrument and a Development Process. International Journal of Teaching and Learning in Higher Education, 23(2), 226-235. Retrieved from http://www.isetl.org/ijtlhe/

Levitt, J. (2003). Complete Guide to Preventive and Predictive Maintenance (1st ed.). New York: Industrial Press.

Lewis, T. (2002). Impact of technology on work and jobs in the printing industry. Implications for vocational 
curriculum. Journal of International Technical Education (JITE), 34(2). Retrieved from http://scholar.lib.vt.edu/ejournals/JITE/v34n2/ Lewis.html

Lynch, R. L. (Ed). (2000). High school career and technical education for the firs decade of the 21 st century. Journal of vocational education research, 25(2), 1-33.

Mangkunegara. (2002). Kesehatan dan Keselamatan Kerja. Retrieved from http://jurnal-sdm.blogspot.com/

Mobley, R. K. (1990). An Introduction to Predictive Maintenance. Van Nostrand Reinhold, New York.

Mohler, J. L. (2007). An instructional strategy for pictorial drawing. Journal of Industrial Teacher Education, 44(3), 5-26.

Nakajima, S. (1989). TPM Development Program: Implementing Total Productive Maintenance. Productivity Press, Cambridge.

Santyasa, I. W. (2007). Landasan Konseptual Media Pembelajaran. Disajikan dalam Workshop Media Pembelajaran bagi Guru-Guru SMA Negeri Banjar. January $10^{\text {th }} 2007$ in Banjar Angkan Klungkung.

Taylor, N., \& Vinjevold, P. (1999). Getting learning right: Report of the President's Education Initative Research Project. Johannesburg, South Africa: Joint Education Trust.

Wongkar, B. (1990). Model perencanaan terpadu pengembangan sekolah. Bandung: FPS IKIP Bandung.

\section{Copyrights}

Copyright for this article is retained by the author(s), with first publication rights granted to the journal.

This is an open-access article distributed under the terms and conditions of the Creative Commons Attribution license (http://creativecommons.org/licenses/by/3.0/). 